\title{
Guest Editorial: Why Near-Death Experiences Intrigue Us
}

\author{
William J. Serdahely, Ph.D. \\ Montana State University
}

In his most recent book, The Light Beyond (1988), Raymond Moody, Jr. includes a chapter with a most provocative title: "Why Near-Death Experiences Intrigue Us." He devotes all of Chapter 4 to exploring this fascinating idea. First, he wonders whether near-death experiencers really died, noting that one intriguing aspect of the near-death experience (NDE) is that NDErs have come closer to death than nonNDErs. Further on in the chapter, he inquires whether the NDE may act as a "religious confirmation" (pp. 68-71) and observes that NDErs tend to be more spiritual, but not necessarily more religious, after their encounter with death.

In his effort to explain why NDEs intrigue us, Moody muses in Chapter 4 whether science would be altered by proof of life after death, a point that is never clearly addressed in this chapter. He ends saying that people would be changed by the proof of an afterlife, but avoids discussing whether or not science would be affected. Moody then goes on to query whether NDEs intrigue us "because they are 'hip'" (pp. 80-83), and concludes that since we have known about them since the writings of Plato, NDEs are not likely to be a passing fancy.

While the above may indeed be valid reasons why NDEs are intriguing to Moody, $I$ am intrigued by them for other reasons, reasons only alluded to in the "Conclusion" to Chapter 4. Moody intimates what is of great fascination to me when he writes, "... death is our greatest mystery and everyone is interested in solving it. NDEs intrigue us

Dr. Serdahely is Professor of Health Science at Montana State University. Requests for reprints should be addressed to Dr. Serdahely at the Health and Human Development Department, Montana State University, Bozeman, MT 59717. 
because they are the most tangible proof of spiritual existence that can be found" (p. 83). Carol Zaleski supported that point when she wrote that each of us knows we will die, and knowing this, we are driven to find ways to make some sense of death $(1987$, p. 12).

Moody never does explicate his concluding comment that NDEs illuminate the fundamental metaphysical questions humans have pondered since the inception of the species, questions that F. W. Ross and T. W. Hills have explored in their book, Questions That Matter Most: Asked by the World's Religions (1954). Ross and Hills' point was that the world's great religions-Buddhism, Christianity, Hinduism, Islam, Judaism, and Taoism-all seek in their own way to answer the same basic metaphysical questions: Who am I? What is real? What is my place in the universe? What shall be my life goals? What is the nature of God? What is the meaning of human life? What happens after death?

Moody hints at possible answers to some of these questions when he mentions in Chapter 4 that NDErs come to regard their bodies as houses for their spirits, that NDEs imply death is a transition to another existence, and that NDErs believe in an afterlife, but in my view he does not go far enough.

I think NDEs intrigue many of us because they help to answer a number of the fundamental spiritual questions many of us have, and to which we are not finding satisfactory answers either from organized religions or from Western science, the reservations of naturalists like Paul Kurtz notwithstanding. These are the very same questions posed by Ross and Hills.

Kurtz (1988) would have us believe that "NDEs can be . . explained by ordinary science," with the explanations residing in physiological mechanisms such as cerebral anoxia or psychological explanations like depersonalization. Not only has he ignored the cogent counterarguments for physiological and psychological explanations put forth by Kenneth Ring (1980), Margot Grey (1985), and Zaleski (1987), but he has also ignored the fundamental metaphysical questions why NDEs intrigue many of us, and for which traditional science has been unable to provide adequate explanations.

Kurtz has also ignored one of the lessons of the history of science, which is that even though contemporary science cannot explain a phenomenon today, the science of tomorrow may well be able to explain it, a point convincingly made by Robert Peel in his book Spiritual Healing in a Scientific Age (1987). Simply recalling the history of the discovery of cells, vaccinations, DNA, and the AIDS virus should be sufficient to demonstrate that at one point science could not explain something we now take for granted. 
I submit that even though the reasons cited by Moody in The Light Beyond may indeed intrigue some people, for others it is the yearning for something more than Western science, orthodox religions, or a materialistic culture can currently provide. The NDE appears to be one way of trying to figure out who we are and what our place in the universe is.

NDErs talk about the separation of their consciousness, spirit, or soul from their bodies, and being able to float above their bodies and look down on the scene below. They often say that who they are is not the physical self. This suggests that something continues to live during the time of clinical death, and hints that the essence of who we are may survive after our bodily processes cease. This component of the NDE helps address the "who am I?" and "what happens after death?" questions of Ross and Hills: we very well may be the energy that leaves the body near death.

NDErs report seeing a life review, during which they reflect on their actions and thoughts and how those have affected others. After the life review, the NDEr decides to return to his or her body, or may be instructed to do so by a deceased relative or spirit entity. The return to the body is often necessitated by a strong sense of a mission that is yet to be fulfilled. One returns to be of service to others, to be more loving, to be more tolerant and compassionate, and/or to seek knowledge of a spiritual nature. This part of the NDE helps to answer the question "what shall be my life goals?" A decrease in the goals of materialism, fame, and power are often new directions for the NDEr. One answer to the question "what is the meaning of human life?" then, is supplied to us by NDErs who now recognize that meaning comes from being more loving, helping others more, and being more forgiving.

NDErs may encounter a light, sometimes described as a being of light, as they travel through the tunnel and beyond. This light is said to be unconditionally and overwhelmingly loving and forgiving. Many NDErs identify the brilliant light of love as God or Jesus. The NDErs' description of God is then somewhat at variance with the depiction of a white-bearded Supreme Being seated on a throne, who is stern and judgmental. According to NDErs, if they are judged for their earthly actions, those judgments come from themselves and not from the loving light. Hence, we get an insight from the NDE into yet another one of the questions the world's great religions try to answer, "what is the nature of God?"

Some NDErs describe being reunited with deceased loved ones and friends in settings said to possess supernatural beauty: colors more vivid than those known to us on Earth, music more splendid than our 
finest symphonies, idyllic pastoral settings with lakes and trees and blue skies. A few NDErs have reported seeing cities or buildings of light, with some of these structures apparently being devoted to learning. These accounts also help us to answer the question "what happens after death?" as we are given at least a partial understanding of what an afterlife may look like.

When asked if the NDE was a dream or hallucination, NDErs, almost to a person, answer negatively. They uniformly believe that what they experienced was real; it really happened to them, even though it is difficult to describe to nonexperiencers and to comprehend, given our present paradigms of reality. NDErs often say their NDE was more real than what we experience as real in this life. Once again, the NDE assists us in addressing yet another question from Ross and Hills: "what is real?"

Another common finding in near-death research is the decrease in the fear of death. NDErs commonly report that after their experience, they have little, if any, fear of death. Many of us nonNDErs have high death anxieties that are perpetuated by a death-denying society. We worry greatly about dying and what will happen after death, another question pondered by the great religions. The NDE helps us to understand that, while we may fear the dying process, death itself need not necessarily be feared.

V. Krishnan (1985) pointed out that, in his view, NDEs do not offer conclusive proof of survival after death. Ring acknowledged this point when he titled his first book Life At Death (1980), implying that all we can really say from near-death research is that something seems to continue to exist at the moment of nearly dying; what lies beyond the border the NDEr is not allowed to cross, we simply do not know for certain.

While Krishnan expressed concern over the view that NDEs hint at survival after death, I and others, on the other hand, are fascinated by that intimation. NDEs intrigue some of use because they do hint at an afterlife, as well as offer tentative speculation about the other metaphysical questions that have long been of interest to humans, questions that go beyond those of interest to Moody in Chapter 4 of The Light Beyond.

\section{References}

Grey, M. (1985). Return from death. London, England: Arkana.

Krishnan, V. (1985). Near-death experiences: Evidence for survival? Anabiosis: The Journal of Near-Death Studies, 5, 21-38. 
Kurtz, P. (1988). Scientific evidence keeps us in the here and now. Psychology Today, 22 (9), 15.

Moody, R. A. (1988). The light beyond. New York, NY: Bantam.

Peel, R. (1987). Spiritual healing in a scientific age. New York, NY: Harper \& Row.

Ring, K. (1980). Life at death: $A$ scientific investigation of the near-death experience. New York, NY: Coward, McCann, and Geoghegan.

Ross, F. W. \& Hills, T. W. (1954). Questions that matter most Asked by the world's religions. Boston, MA: Beacon Press.

Zaleski, C. (1987). Otherworld journeys: Accounts of near-death experience from medieval and modern times. New York, NY: Oxford University Press. 